\title{
Porovnání obsahu sestav českých a zahraničních závodnic moderní gymnastiky
}

\section{The comparison of the routines contents of Czech and foreign rhythmic gymnastics competitors}

\author{
Iveta Šimůnková, Viléma Novotná \\ Fakulta tělesné výchovy a sportu, Univerzita Karlova v Praze
}

\begin{abstract}
Abstrakt:
Výkon v moderní gymnastice je propojením techniky cvičení bez náčiní, techniky cvičení s náčiním a emočního ztvárněni linie hudby jako předlohy pro výsledný pohybový obsah závodních choreografií. Na základě analýzy videozáznamů individuálních sestav českých a světových moderních gymnastek a z hlediska porovnání počtu prvků obtižnosti v sestavách s náčiním ve vztahu k platným pravidli̊m soutěži byla hodnocena aktuální úspěšnost vybraných závodnic. Výsledky rozboru dokládaji, že české gymnastky zařazují do svých volných sestav prvky obtižnosti nižši hodnoty, což ve srovnáni se světovou elitou ukazuje na celkově nižši úroveñ zvládnutí techniky cvičení bez náčini. Porovnání výsledků analýzy provokuje potřebu změn náplně našich volných sestav. Jedná se předevšim o nutnost zařadit prvky obtižnosti vyššího ohodnocení, založené na osvojení si základních pohybových struktur z inventáre gymnastických dovedností. Světové gymnastky mají ve svých sestavách v prüměru až o čtvrtinu více prvki nejvyšši hodnoty než české reprezentantky. Pro požadovanou úroveň zvládnutí dovedností s nejvyšši hodnotou je zapotřebi systematizovat sportovni př́pravu mládeže, realizovat vlastní tréninkový proces s respektováním věku vybraných gymnasteks výhledem očekávaného výkonu a neopomíjet požadavek odbornosti trenérek v procesu péče o sportovně talentované jedince.
\end{abstract}

\begin{abstract}
:
Performance in rhythmic gymnastics (RSG) is in connection with techniques without hand apparatus, techniques with hand apparatus and emotional rendition of music line as a template for the final movement content in competitive choreographies. Based on the video analysis of individual exercises of Czech and foreign gymnasts and in terms of comparing the number of difficulty elements in each routines, in relation to the code of points in RSG was assessed current success of selected competitors. From the results of the analysis is clear, that the Czech gymnasts choose lower level of difficulty elements in their optional routines, which in comparison with the world elite gymnasts show an overall lower level of mastery of technique without hand apparatus. Comparison of the analysis results notes the need for changes in choosing difficulty elements in optional routines of czech gymnasts. This is especially the need to include difficulty elements with higher ranking, for which is important to learn the basic movement structures of gymnastic skills inventory. Elite gymnasts choose in their routines a quarter more of the highest value elements than Czech national team.

For the mastery level of the skills with the highest value is needed to systematize youth sports training to realize training process in relation to age of gymnasts with the view of expected performance and coaches expertise in the process of care for sport gifted youth.
\end{abstract}

Klíčová slova: moderní gymnastika, výkon, prvky obtižnosti, pravidla $M G$

Keywords: rhythmic gymnastics, performance, difficulty elements, RSG code of points

Úvod

Sport, jako fenomén současné doby, zasahuje významně jak do života jednotlivce, tak celé společnosti. Je chápán jako diplomatický tah a reprezentace země, jako sebeprezentace a pohybová seberealizace člověka, stává se každodenní potřebou určité skupiny populace, podílí se na vytváření hodnot zdravého životního stylu. Motivaci k výběru pohybové aktivity ovlivňuje i struktura výsledného sportovního výkonu. 
Mezi sporty má zvláštní místo sportovní odvětví moderní gymnastika (MG, do roku 1969 známá pod názvem umělecká gymnastika), která je jediným sportem určeným výhradně dívkám a ženám. I na výsledný výkon jsou kladeny specifické jedinečné požadavky založené nejen na určitých vrozených dispozicích a míře osvojených dovedností, ale také na předpokladu ztvárnit pohyb s respektováním estetických kritérií a s výrazovým prožitkem. Při hodnocení celkového výkonu v moderní gymnastice je důraz kladen na přesnost a estetičnost pohybového projevu gymnastky s vazbou na emocionální vyjádření hudebního doprovodu (Št’astná \& Mihule, 1993). Moderní gymnastika ve svém obsahu zahrnuje velký počet pohybových dovedností - cvičení bez náčiní (tzv. prvky obtížnosti, mezi které řadíme skoky, obraty, ohebnostní a rovnovážné tvary) a s náčiním (švihadlo, obruč, míč, kužele, stuha). Nedílnou součástí pohybové gramotnosti moderních gymnastek je, vedle rozvoje pohybových schopností a nácviku dovedností, vlastní tvořivost odrážející osobní styl gymnastky a její umění výrazově ztvárnit hudebně-pohybovou kompozici (Šimůnková, Novotná \&Vorálková, 2010). Současná pravidla moderní gymnastiky kladou na závodnice vysoké nároky především v oblasti flexibility, v požadavku maximálního rozsahu pohybu, který je v dnešním vrcholovém klání limitujícím faktorem výkonu v soutěži MG. Sportovní výkon tedy spočívá jak v úrovni zvládnutí pohybových struktur daných mezinárodně platnými pravidly, tak i ve výrazovém projevu gymnastky. Objektivněji posuzovanou stránkou hodnocení sestav gymnastek je úroveň zvládnutí techniky provedení pohybu a množství zařazených prvků obtížnosti přesně definovaných pravidly. Projev gymnastky a soulad pohybu s hudbou je subjektivním aspektem hodnocení. Problémem je, do jaké míry ovlivňuje četnost zařazených prvků v sestavě výsledné hodnocení výkonu a jaké jsou trendy vývoje obsahu sestav našich gymnastek v porovnání s úspěšnými zahraničními gymnastkami.

Tento př́spěvek vznikl v rámci projektu Specifického vysokoškolského výzkumu 2012-265603 a Výzkumného záměru UK FTVS, MSM 0021620864.

\section{Metodika}

Cílem příspěvku je na základě rozboru mezinárodně platných pravidel, jako výchozí literatury pro předmět zkoumání, a analýzy volných sestav stanovit jejich obsah na další olympijské období od roku 2013. Předmětem zkoumání je počet zařazených prvků obtížnosti ve volných individuálních sestavách gymnastek. Celkově je v rozboru zahrnuto čtyřicet sestav cvičených osmi gymnastkami, a to čtyřmi gymnastkami z ČR (X ČR $1-4$ ) a čtyřmi gymnastkami přední světové úrovně (X 1 - 4). Př́spěvek vychází z metody analýzy, která byla použita při pozorování videozáznamů soutěžních sestav předních seniorských gymnastek od šestnácti let z OH 2004 v Aténách, OH 2008 v Pekingu a z MS 2011 v Montpellier, poslední světové soutěže před OH 2012 v Londýně. Analýzou dle Kováŕe a Blahuše (1973) chápeme jednu ze základních logických postupů, které jsou podstatou myšlenkové části vědecké práce. Pro přehled získaných rozborů videozáznamů je vytvořena jednoduchá tabulka s četností všech vyskytovaných prvků obtížnosti dle jejich hodnot obtížnosti v dílčích sestavách jednotlivých gymnastek. Metodou procentuálního vyjádření četnosti zařazení prvků obtížnosti v sestavách a vypočítáním průměrů jsou výsledky zkoumání vyjádřeny matematicky. Metoda extrapolace neboli výběr dat charakterizujících minulý vývoj a následná modelace pro budoucí znázornění předmětu prognózy (Tilinger, 2004) stanovuje možná východiska pro zařazování prvků obtížnosti do sestav moderních gymnastek v nadcházejícím novém olympijském cyklu. Výsledky budou použity především jako podklad pro úpravu obsahu sportovní př́pravy v MG na další OH cyklus 2013 - 2016. Pro oblast řízení sportovního tréninku ve vrcholovém sportu je použita prognóza, která se zabývá analýzou minulého vývoje, prognostickými modely další výkonnosti či vývojem celého systému sportu. Prognóza výkonů a modelových charakteristik vytváŕí předpoklady pro kvalitní tvorbu plánu tréninků, zvýšení efektivity př́ípravy vrcholových sportovců a pro stanovení strategie vývoje sportu a sportovní výkonnosti od dětí a mládeže až po seniory. Je podstatné si uvědomit, že kvalitní práce s dětmi a mládeží ovlivňuje úspěch v kategorii dospělých (Tilinger, 2004).

\section{Teoretická východiska}

\section{Pravidla moderní gymnastiky a prvky obtížnosti}

Pravidla MG, jako právní složka techniky (Krištofič et al., 2009), jsou ustanovena technickou komisí moderní gymnastiky Mezinárodní gymnastické federace (Federation International de Gymnastigue - FIG) vždy v roce konání LOH s platností na čtyři roky. Tedy i v letošním roce dojde k úpravám stávajících platných pravidel na období 2013 - 2016 (FIG, 2008, 2012). Základní myšlenkou pravidel MG obecně je hodnocení techniky cvičení 
bez náčiní - technická hodnota prvků obtížnosti, hodnocení techniky cvičení s náčiním - technická hodnota obtížnosti s náčiním, srážky v provedení a uměleckém dojmu (tzv. artistika). Vzhledem $\mathrm{k}$ tomu, že v pravidlech od roku 2004 (FIG, 2004) se vyskytují obdobné a téměř neměnné prvky obtížnosti bez náčiní, je pozornost zaměřena na jejich četnost $\mathrm{v}$ závodních sestavách a následnou prognózu zařazení prvků obtížnosti v následujícím čtyřletém olympijském cyklu.

Základní prvky obtížnosti jsou rozděleny do čtyř skupin - skoky, obraty (ve výponu), ohebnostní tvary (prvky s velkým kloubním rozsahem) a rovnovážné tvary (ve výponu). V jednotlivých sestavách s náčiním jsou vymezeny charakteristické prvky obtížnosti, které musí v sestavě převažovat (tab. 1).

Tab. 1 Převažující prvky obtižnosti v sestavách s náčiním

\begin{tabular}{|l|l|l|l|l|}
\hline Švihadlo & Skoky & Obraty & & \\
\hline Obruč & Skoky & Obraty & Ohebnostní tvary & Rovnovážné tvary \\
\hline Míč & Ohebnostní tvary & Skoky & & \\
\hline Kužele & Rovnovážné tvary & Obraty & & \\
\hline Stuha & Obraty & Skoky & & \\
\hline
\end{tabular}

Pouze tedy v sestavě s obručí se povinně musí vyskytovat všechny čtyři skupiny prvků obtížnosti. Praxe ukázala, že i přes stanovený požadavek je většina sestav s náčiním choreograficky rovnoměrně složena ze všech skupin prvků obtížnosti. Změna pravidel pro následující období vychází z tohoto zjištění, a proto povinnost zařazení vybraných skupin prvků bez náčiní již nebude vyžadována (FIG, 2012). V sestavách budou muset být z hlediska výběru prvků zastoupeny všechny skupiny prvků obtížnosti - tak jako v sestavě s obručí dle současných pravidel.

Jednotlivé prvky obtížnosti mají přesně stanovenou hodnotu od 0,1 (značeno A) do 1 bodu (značeno J) a více. Horní hranice není omezena. Setkáváme se tedy s prvky $\mathrm{K}$ s hodnotou 1,1 bodu a více. Jedná se především o kombinace prvků a násobné rotace $\mathrm{v}$ obratech. Součet hodnot všech zařazených prvků, maximálně dvanáct obtížností v jedné sestavě, nesmí překročit celkovou výchozí známku 10 bodů v kategorii seniorek.

Pro potřeby příspěvku jsou hodnoty obtížností uspořádány do čtyř hlavních skupin (tab. 2). První skupinu obtížností dle stávajících pravidel tvoří prvky A - F z důvodu požadavku jejich zvládnutí již v kategorii mladších gymnastek (do 11 let) a vzhledem k jejich méně častému zařazování v kategorii seniorek (od 16 let).

Změna pro rok 2013 se chystá v jiném uspořádání hodnot prvků obtížnosti, a to od 0,1 do 0,5 bodu a více, tedy A - E a více. Prvky obtížnosti budou rozděleny pouze do 3 základních skupin - skoky, obraty a rovnovážné tvary (FIG, 2012). Je nutno zdůraznit, že maximální počet obtížností bude snížen z dvanácti na devět prvků $\mathrm{v}$ jedné sestavě. Prvky s obtížností $\mathrm{F}$ a více bude možné provádět pouze ve skupině obratů. Vzhledem $\mathrm{k}$ výše uvedeným změnám a požadavkům na sestavy nejvyšší kategorie seniorek byla provedena analýza sestav, to znamená počet zařazených prvků obtížnosti nejvyšší hodnoty v porovnání světových gymnastek a českých reprezentantek od roku 2004 do roku 2011.

Tab. 2 Hodnoty prvki̊ obtižnosti ve dvou olympijských cyklech

\begin{tabular}{|l|l|}
\hline \multicolumn{1}{|c|}{ Pravidla MG 2009 - 2012 } & \multicolumn{1}{|c|}{ Pravidla MG 2013 - 2016 } \\
\hline $\begin{array}{l}\text { prvky obtî̃nosti s hodnotou od 0,1 do 0,6 bodu } \\
\text { (značeno A - F) }\end{array}$ & $\begin{array}{l}\text { prvky obtĩznosti s hodnotou 0,1 a 0,2 bodu } \\
\text { (značeno A - B) }\end{array}$ \\
\hline $\begin{array}{l}\text { prvky obtĩnnosti s hodnotou 0,7 - 0,8 bodu } \\
\text { (značeno G a H) }\end{array}$ & $\begin{array}{l}\text { prvky obtĩnnosti s hodnotou 0,3 - 0,4 bodu } \\
\text { (značeno C - D) }\end{array}$ \\
\hline $\begin{array}{l}\text { prvky obtî̃nosti s hodnotou 0,9 - 1,0 bod } \\
\text { (značeno I a J) }\end{array}$ & $\begin{array}{l}\text { prvky obtî̃nosti s hodnotou 0,5 bodu } \\
\text { (značeno E) }\end{array}$ \\
\hline $\begin{array}{l}\text { prvky obtî̃nosti s hodnotou 1,1 bodu a více } \\
\text { (značeno K a dále) }\end{array}$ & $\begin{array}{l}\text { prvky obtî̃nosti s hodnotou 0,6 bodu a více } \\
\text { (značeno F a dále) }\end{array}$ \\
\hline
\end{tabular}


Zvládnutí nejtěžších prvků obtížnosti s nejvyšší hodnotou by mělo být jedním z hlavních cílů sportovní př́pravy talentovaných gymnastek. Nezbytná je systematická a soustavná př́prava a přměřený trénink dané věkové kategorie a působení trenérů s nejvyšší odborností v problematice přípravy sportovně talentované mládeže (Perič, 2006, 2008). Česká moderní gymnastika se již dlouhodobě potýká s problémem nedostatečné připravenosti gymnastek ve vrcholové etapě tréninku. To je zejména důsledek neodborného vedení v raně specializovaném úseku př́pravy a nedostatečné osvojení si základních pohybových dovedností jako stavebního kamene pro navazující prvky obtížnosti (FIG, 2005). Nejen v gymnastických sportech je úroveň vytvořené pohybové gramotnosti zásadní podmínkou pro další sportovní přípravu (Stafford \& Balyi, 2005). Bez osvojení si uvědoměle řízeného pohybu a dané techniky pohybu se nelze naučit další obtížnější prvky z inventáře gymnastických činností a specifických dovedností. Mezi základní pohybové dovednosti je zařazována oblast rozvoje pohybových schopností, problematika držení těla, základní lokomoce, rytmizace pohybu a manipulace s náčiním. Mezi specifické sportovní dovednosti v moderní gymnastice je řazeno osvojení si techniky cvičení bez náčiní, techniky cvičení s náčiním a techniky klasického tance. Všechny tyto složky jsou neoddělitelnou součástí pozdějšího sportovního výkonu v moderní gymnastice.

\section{Výsledky}

Vzhledem k pravidlům MG pro rok 2004, kdy jednodušší prvky obtížnosti byly spojovány podle přesně stanovených propojovacích pohybů, do tzv. kombinací, není možné níže uvedené hodnocení sestav z OH v Aténách porovnávat s dalšími vyhodnoceními z pozdějších let Tabulka 3 i přesto ukazuje, že na Hrách XXVIII. olympiády v Pekingu byla světová špička MG z hlediska výběru nejsložitějších prvků obtížnosti před reprezentací ČR. I přes jiné hodnocení výkonu je patrný výběr více prvků obtížnosti v rozmezí $0,7-0,8$ a vždy po dvou prvcích úrovně $0,9-1,0$ u světové gymnastky. Je nutno podotknout, že v příspěvku je uveden pouze počet zařazených prvků bez ohledu na případné chyby v provedení (držení těla, technika provedení, pád náčiní apod.).

Tab. 3 Prvky obtižnosti na OH 2004 v posouzení dle platných pravidel z roku 2008

\begin{tabular}{|c|c|c|c|c|c|c|}
\hline \multicolumn{2}{|c|}{ Prvky obtižnosti OH 2004} & \multirow{2}{*}{\multicolumn{4}{|c|}{\begin{tabular}{|c|} 
počet prvků dané obtížnosti \\
hodnoty obtižnosti (dle pravidel 2008) \\
\end{tabular}}} & \multirow[b]{3}{*}{$\begin{array}{r}\text { celkem } \\
\text { prvků } \\
\end{array}$} \\
\hline \multirow[b]{2}{*}{ gymnastka } & \multirow[b]{2}{*}{ náčiní } & & & & & \\
\hline & & $\begin{array}{l}A-F \\
<0,6\end{array}$ & $\begin{array}{c}\text { G }-H \\
0,7-0,8\end{array}$ & $\begin{array}{c}I-J \\
0,9-1,0\end{array}$ & $\begin{array}{c}K \\
1,1<\end{array}$ & \\
\hline \multirow{4}{*}{$\mathbf{X} 1$} & obruč & 14 & 6 & 2 & & 22 \\
\hline & míc & 11 & 8 & 2 & & 21 \\
\hline & kužele & 11 & 7 & 2 & & 21 \\
\hline & stuha & 12 & 8 & 2 & & 22 \\
\hline \multirow{4}{*}{ X ČR 1} & obruč & 13 & 5 & & & 18 \\
\hline & míc & 16 & 2 & & & 18 \\
\hline & kužele & 17 & 2 & & & 19 \\
\hline & stuha & 15 & 4 & & & 19 \\
\hline
\end{tabular}


Tab. 4 Prvky obtižnosti na OH 2008 v posouzení dle platných pravidel z roku 2008

\begin{tabular}{|c|c|c|c|c|c|c|c|}
\hline \multicolumn{2}{|c|}{ Prvky obtižnnostl OH 2008} & \multirow{2}{*}{\multicolumn{4}{|c|}{\begin{tabular}{|c|} 
pođet pryků dané obtižnosti \\
hodnoty obtžností (dle pravidel 2008)
\end{tabular}}} & & \\
\hline \multirow[b]{2}{*}{ gymnastka } & \multirow[b]{2}{*}{ náçní } & & & & & & \\
\hline & & $\begin{array}{l}\text { A - F } \\
<0,6\end{array}$ & $\begin{array}{c}\text { G }-H \\
0,7-0,8\end{array}$ & $\begin{array}{c}\text { I - J } \\
0,9-1,0\end{array}$ & $\begin{array}{c}K \\
1,1< \\
\end{array}$ & typ obtižnostl dle pravidel & $\begin{array}{l}\text { celkem } \\
\text { prvků }\end{array}$ \\
\hline \multirow{4}{*}{$\mathbf{X} 2$} & కvihadlo & 6 & 9 & 1 & 2 & 2 obraty & 18 \\
\hline & obrux & 1 & 7 & 4 & 2 & 2 obraty & 14 \\
\hline & kužele & 5 & 3 & & 4 & 2 obraty, 2 výdrže & 12 \\
\hline & stuha & 3 & 6 & 1 & 5 & 5 obratů & 15 \\
\hline \multirow{4}{*}{$\mathbf{x} 3$} & కvihadlo & 8 & 5 & 1 & 2 & 4 obraty & 16 \\
\hline & obrux & 6 & 3 & 2 & 3 & 4 obraty & 14 \\
\hline & kužele & 5 & 5 & & 3 & 2 obraty, 1 ohebnost & 13 \\
\hline & stuhạ & 5 & 4 & 2 & 3 & 4 obraty & 14 \\
\hline $\begin{array}{l}\text { procentuální } \\
\text { vyjádirení }\end{array}$ & ctyæo] & 33,65 & 36,2 & 9,5 & 20,65 & & \\
\hline \multirow{4}{*}{ X ČR 2} & క̌vihadlo & 5 & 7 & 1 & 1 & 1 výdrž & 14 \\
\hline & obruč & 9 & 6 & 1 & & & 16 \\
\hline & kužele & 10 & 5 & 1 & & & 16 \\
\hline & stuha & 5 & 6 & 3 & 1 & 1 obrat & 15 \\
\hline \multirow{4}{*}{ X ČR 3} & švihadlo & 6 & 9 & 1 & & & 16 \\
\hline & obrux & 10 & 5 & & & & 15 \\
\hline & kužele & 9 & 5 & 2 & & & 16 \\
\hline & Stuha & 5 & 8 & 2 & 1 & 1 obrat & 16 \\
\hline $\begin{array}{l}\text { procentuální } \\
\text { vyjádření }\end{array}$ & ctyłboj & 47,6 & 41,1 & 8,9 & 2,4 & & \\
\hline
\end{tabular}

Tabulka 4 je již podložena pravidly MG z velké části totožnými s pravidly platnými v současné době. OH 2008 byly pro českou reprezentaci málo povzbudivé, protože české moderní gymnastky si nominaci nevybojovaly. Pro porovnání zařazovaných prvků obtížnosti jsou vybrány dvě přední světové gymnastky a dvě nejlepší gymnastky té době v ČR. Rozdíl je opět markantní. Gymnastky světové úrovně měly v sestavě z 20,65 \% prvky obtížnosti úrovně 1,1 bodu (průměrně tři prvky v sestavě) a více a reprezentantky ČR pouze 2,4 \% (tedy v průměru méně než jeden prvek v sestavě), prvky A - F zařazovaly české závodnice téměř z $50 \%$. 
Tab. 5 Prvky obtižnosti MS 2011 v posouzeni dle platných pravidel z roku 2008

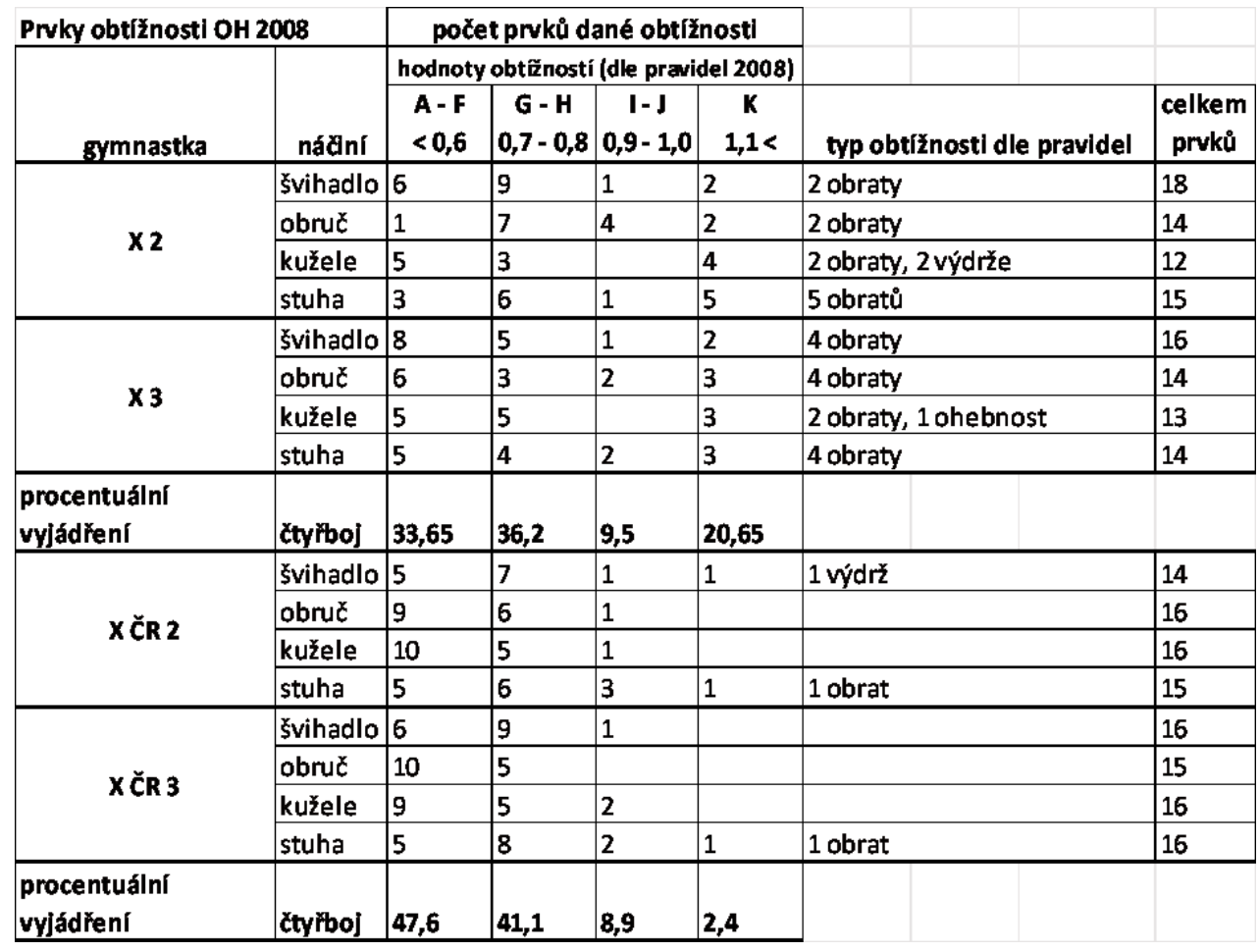

Pro českou moderní gymnastiku je nelichotivý i letošní olympijský rok. Česká reprezentace se opět na OH neprobojovala. Tabulka 5 tak uvádí obtížnosti sestav českých gymnastek v porovnání se světovou elitou z MS 2011 dle platných pravidel (FIG, 2008). Zařazení prvků obtížnosti se procentuálně zvýšilo u obou sledovaných skupin - svět a ČR. Světové gymnastiky mají v sestavách prvky obtížnosti nejvyšší hodnoty v průměru čtyři $(34,5 \%)$ a české gymnastky necelých 8,5 \%, tedy jeden prvek na jednu sestavu. Prvky obtížnosti $\mathrm{G}-\mathrm{H}$ byly oproti předešlému zkoumání navýšeny z 41,4 \% na 62,55 \%. Což je pro českou gymnastiku povzbudivé. Je zřejmé, že úroveň zvládnutí (osvojení) obtížnějších prvků s nejvyšší hodnotou je v ČR na nižší úrovni. Pokud se chceme jako Česká republika vrátit na vrcholovou úroveň, je potřeba se v této oblasti zaměřit na technickou připravenost dívek - tedy na několikrát zmiňované prvky obtížnosti. Další složkou výkonu je samožrejmě technika cvičení s náčiním, která ale není předmětem zkoumání.

Je nutno se vrátit ke konstatování, že „kvalitní práce s dětmi ovlivňuje úspěch v dospělosti“. Problém je především ve výběru a péči o sportovně talentovanou mládež, a to jak z hlediska nedostačujícího profesního (profesionálního) vedení, tak z hlediska upřednostnění osobního zájmu a úspěchu gymnastky nad kvalitou př́pravy (Novotná, 1983). V MG se stále setkáváme s ranou specializací a neadekvátním tréninkem dětí.

\section{Diskuse}

Je důležité uvést, že každá gymnastka musí před soutěží předložit tzv. oficiální formulář se zápisem sestavy. Tyto formuláře pro analýzu prvků obtížnosti nebyly k dispozici, ale tento nedostatek není podstatný a neovlivňuje výsledky. Uvedené poznatky jsou shrnuty do tabulky 6 , která prezentuje celkové zastoupení prvků obtížnosti $\mathrm{v}$ sestavách $\mathrm{s}$ jednotlivým náčiním. V sestavách $\mathrm{s}$ kuželi a se stuhou mohou převažovat rovnovážné tvary a obraty, proto je zastoupení prvků obtížnosti K a více vyšší. Vzhledem k tomu, že dva roky bylo v moderně gymnastickém čtyřboji švihadlo a po dva roky míč, spojili jsme výsledky v obou náčiních do jednoho hodnocení. V dalším období je pro plán př́ípravy směrodatné především cvičení s obručí z důvodu rovnoměrného zařazení prvků obtížnosti ze všech skupin. Toto pravidlo bude platné pro všechny sestavy s náčiním od roku 2013. 
Tab. 6 Prvky obtížnosti 2008-2012

\begin{tabular}{|c|c|c|c|c|c|c|}
\hline \multicolumn{2}{|c|}{ Prvky obtí̌nosti 2008 - 2012} & \multirow{2}{*}{\multicolumn{4}{|c|}{\begin{tabular}{|c|} 
počet prvků dané obtižnostiv \% \\
hodnoty obtižnosti (dle pravidel 2008) \\
\end{tabular}}} & \multirow[b]{3}{*}{$\begin{array}{l}\text { celkem } \\
\text { prvků }\end{array}$} \\
\hline \multirow[b]{2}{*}{ gymnastka } & \multirow[b]{2}{*}{ náčiní } & & & & & \\
\hline & & $\begin{array}{l}\mathbf{A}-\mathbf{F} \\
<0,6\end{array}$ & $\begin{array}{c}\text { G }-H \\
0,7-0,8 \\
\end{array}$ & $\begin{array}{c}1-J \\
0,9-1,0 \\
\end{array}$ & $\begin{array}{c}K \\
1,1<\end{array}$ & \\
\hline \multirow{4}{*}{$\begin{array}{c}\text { gymnastky svètové } \\
\text { úrovnè } \\
\text { (v procentech) }\end{array}$} & obruč & 21,5 & 44 & 13,5 & 21 & 12 \\
\hline & Švih.,míc & 27,5 & 50 & 3 & 19,5 & 12 \\
\hline & kužele & 26,5 & 39 & & 34,5 & 12 \\
\hline & stuha & 18,5 & 43 & 5 & 33,5 & 12 \\
\hline $\begin{array}{c}\text { procentuální } \\
\text { vyjádření }\end{array}$ & ctyî́boj & 23,5 & 44 & 5,4 & 27,1 & \\
\hline \multirow{4}{*}{$\begin{array}{l}\text { gymnastky úrounè } \\
\text { Mistrovství CR } \\
\text { (v procentech) }\end{array}$} & obruč & 44,5 & 44,5 & 9 & 2 & 12 \\
\hline & క̌vih.,míc & 27,5 & 61,5 & 7,5 & 3,5 & 12 \\
\hline & kužele & 41 & 48 & 5,5 & 5,5 & 12 \\
\hline & stuha & 25,5 & 49 & 18 & 7,5 & 12 \\
\hline $\begin{array}{c}\text { procentuální } \\
\text { vyjádření }\end{array}$ & čtyr̈boj & 34,5 & 51 & 10 & 4,5 & \\
\hline
\end{tabular}

Z tabulky 6 vyplývá, že české gymnastky zařazovaly nejtěžší prvky ze 4,5 \% a jednodušší z 34,5 \%, světové gymnastky prvky nejvy̌šsí úrovně předvedly z 27,1 \% a snadnější z 23,5 \%. Tabulka 7 odpovídá tab. 6, kdy z celkového počtu devět prvků a z procentuálního vyjádření zastoupení prvků v období 2008 - 2011 vyplývá počet prvků obtížnosti s hodnotami dle pravidel platných pro olympijský cyklus od roku 2013 (FIG, 2012). Vzhledem k tomu, pravidla povolují pouze prvky obtížnosti obraty a rovnovážné tvary vyšší hodnoty než 0,6 bodu, je podstatné se v př́ipravě zaměřit na rotační a rovnovážnou př́ípravu (Jasterjemskaia \& Titov, 1999). Dále předpokládám, že dojde $\mathrm{k}$ určitému nárůstu zařazených prvků obtížnosti v průběhu celého období, jako tomu je v rozdílu mezi rokem 2008 a 2011. Navýšení u světových gymnastek bylo o 13,85 \% a u českých gymnastek o $5,95 \%$. Z toho usuzuji, že české moderní gymnastky budou mít v sestavě zařazen alespoň jeden prvek obtížnosti 0,6 a více (dříve 1,1 a více). Gymnastky světové úrovně v průměru tři prvky.

Tab. 7 Počet prvků obtižnosti 2013 - 2016 dle analýzy 2008 - 2011

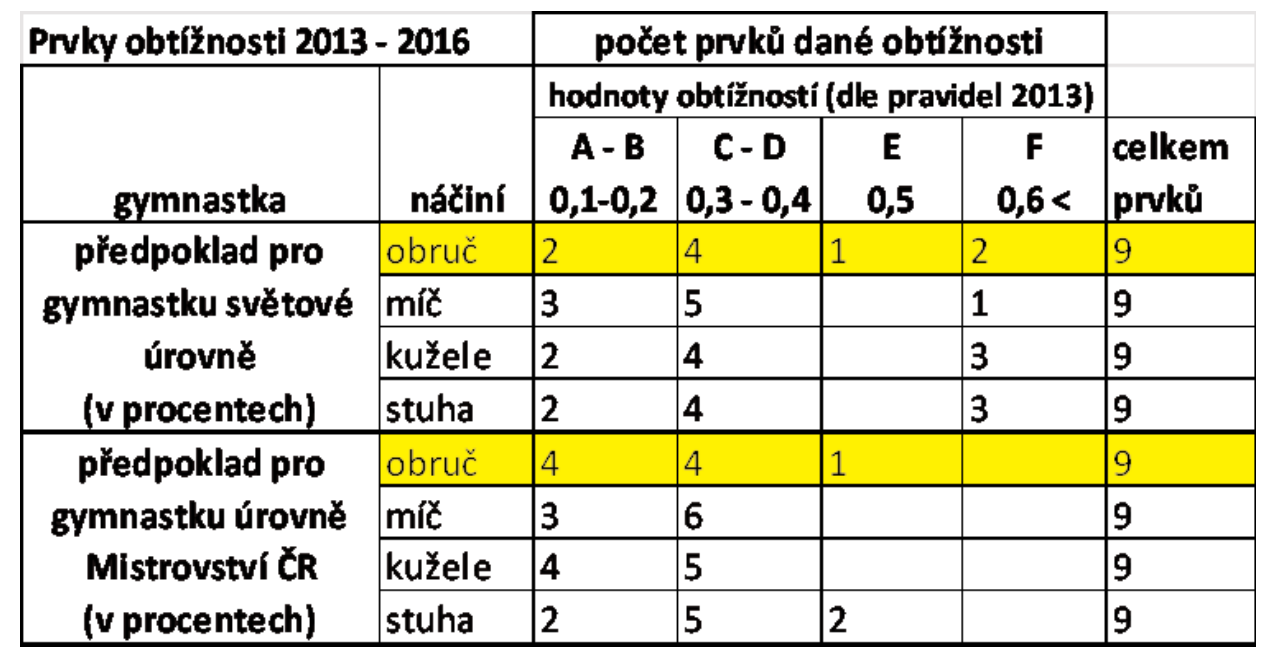




\section{Závěry}

Analýzou videozáznamů z let 2004, 2008 a 2011 byly pomocí jednoduchých matematických metod vyčísleny počty prvků obtížnosti zařazovaných do volných sestav MG dle platných pravidel daného období s prognózou zařazení prvků v období nového olympijského cyklu. Historický vývoj ukazuje, že světové úrovně naše moderní gymnastika nedosahuje a co víc, „svět“" se nám velmi rychle vzdaluje. Pokud chceme jedinečné dívčí sportovní odvětví v ČR vrátit na olympijské závodiště, čeká trenérky, a gymnastky především, mnoho práce a úsilí. Odborný přístup v plánování a ve vedení tréninků je základním předpokladem pro zvýšení stávající úrovně zvládnutých prvků obtížnosti, které jsou jedním z hlavních komponent hodnocení výkonu. Současným trendem moderní gymnastiky jsou tedy takové struktury obtížnosti, které jsou i pro odborníky prvky originálními a zvládnutými na nejvyšší hodnotové hranici. Nesmí se zapomínat na skutečnost, že složité pohybové struktury mohou logicky navazovat jen na osvojené základní dovednosti.

\section{Literatura}

Federation International de Gymnastique - FIG (2004) Code of points - Rhythmic Gymnastics. Lausanne, Switzerland: FIG.

Federation International de Gymnastique - FIG (2008) Code of points - Rhythmic Gymnastics. Lausanne, Switzerland: FIG.

Federation International de Gymnastique - FIG (2012) Code of points - Rhythmic Gymnastics. Lausanne, Switzerland: FIG.

Federation International de Gymnastique - FIG (2005). Age Group Developement Program. Lausanne, Switzerland: FIG.

Jastrjembskaia, N. \& Titov, Y. (1999). Rhythmic Gymnastics. Champaign, Ill, USA: Human Kinetics.

Kovár̆, R. \& Blahuš, P. (1973). Stručný úvod do metodologie. Praha: Univerzita Karlova.

Krištofič, J., et al. (2009). Gymnastika. Praha: Karolinum.

Novotná, V. a kol. (1983). Celoročni program sportovní připravy žactva v oddílech MG. Praha: ÚV ČSTV.

Perič, T. (2008). Sportovni príprava dětí. Praha: Grada Publishing.

Perič, T. (2006). Výběr sportovních talentü. Praha: Grada Publishing.

Stafford, I. \& Balyi, I. (2005). Coaching for longterm ahtlete development. Coachwise, UK: Sports coach.

Šimůnková, I., Novotná, V. \& Vorálková, J. (2010) Struktura složek pohybové gramotnosti pro sportovní odvětví moderní gymnastika. Studia Kinanthropologica, roč. 11 (č. 2): s. 110-119.

Št’astná, D. \& Mihule, J. (1993). Rytmická gymnastika. Praha: Karolinum.

Tilinger, P. (2004). Prognózování vývoje výkonnosti ve sportu. Praha: Karolinum. 